
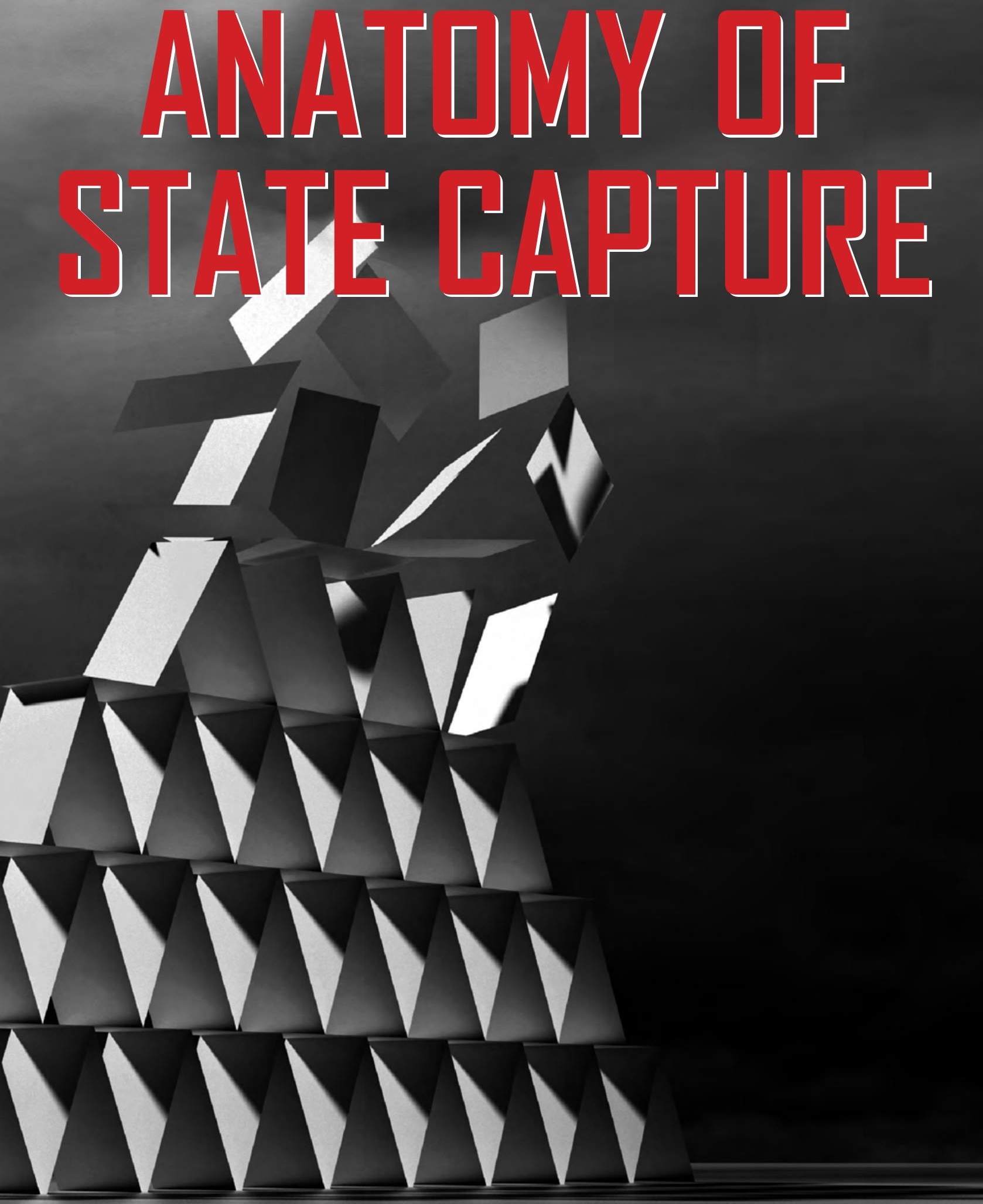

Nina Callaghan, Rabyn Foley and Mark Swilling (EDITuRS) 


\section{RISKY BUSINESS: CORPORATE ETHICS IN THE ERA OF CAPTURE}

Rob Rose

Michael Katz, a professor and one-time lawyer for former President Nelson Mandela, tells a story that illuminates just how the years of state capture caused a slow rot in the private sector. At the height of Jacob Zuma's Presidency, one Executive of a large South African company listed on the country's stock exchange, the JSE, came to his office at law firm ENS for a chat. This Executive was looking for advice on how to structure a deal he wanted to put in place and Katz, as the country's pre-eminent corporate lawyer, was the man to ask. Katz was aghast at the man's plan. "I told him, well, what you're suggesting would not only breach the JSE listings requirement, but also the Companies Act", he says. He stared back at Katz, apparently incredulous. "Michael", he replied, "why are you talking to me about a breach of the JSE's listing rules? Just look at what's happening in the country around us!" (Michael Katz, 2019).

It was a sobering moment for Katz, not least since he was one of the original architects of the King Code of Corporate Governance, the set of principles around which all South Africa's blue-chip companies are meant to organise themselves. "This was a wake-up call", says Katz. "The wide scale looting, and absence of integrity in the public sector always had the potential to spill over into the private sector. Especially because of the lack of prosecutorial consequence for those who broke the rules", he says (Michael Katz, 2019). This lack of consequence had emboldened those who might otherwise have been less inclined to cut corners.

It is a simple formula, says Katz. If someone is considering something ethically dubious, like insider trading, the trajectory of thinking goes like this: first, they consider the likelihood of detection and apprehension; second, if they're caught, will there be a successful prosecution; and third: how severe is the sentence. "The last thing people look at is the severity of the sentence. If I don't think there's any chance I'll be apprehended, I won't be worried whether the sentence is 10 -years in jail, or 20-years" (Michael Katz, 2019).

Looked at through that lens, it's entirely clear why the knee-jerk reaction of regulators and Parliamentarians, to call for harsher sentences for corporate crime, is entirely the wrong medicine. If no one is being brought to book in the first place, it is pointless. 
It is a sobering analysis. And this fraying of corporate ethics over the decade from 2009 which Katz describes has manifested in an alarming smorgasbord of accounting scandals. This, in turn, has had a severe dampening effect on foreign investment in South Africa - one of the few tonics that could meaningfully shift the country's sub-1\% GDP growth.

In 2017, for example, inward foreign investment into SA totalled $\$ 2$ bn - less than half the annual average of $\$ 4,5 \mathrm{bn}$ which SA got between 2005 and 2007 . Though this rebounded to $\$ 5.3 \mathrm{bn}$ in 2018 , it is some way off all-time records (United Nations Conference on Trade and Development [UNCTAD]; 2019).

Consider the big daddy of the country's corporate scandals: retailer Steinhoff.

\subsection{ENRON, AFRICA STYLE}

It seems somewhat incongruous that a company that began life as a furniture trader in 1964 in the sleepy northern German town of Westerstede, where the annual midsummer rhododendron festival is front page news, holds the ignominious distinction of being South Africa's Enron.

Yet, this is the case of Steinhoff. Started by crusty German entrepreneur Bruno Steinhoff, based on the premise of buying furniture cheaply from behind the Iron Curtain and selling it in the west, the turning point came in 1995 when a friend introduced him to a South African lounge suite manufacturer from Ga-Rankuwa named Markus Jooste. "From the beginning, I found him to be a wonderful man. Markus would also tell people: 'This is my father'. And to me, I thought of myself as his father," said Bruno Steinhoff (2018).

Jooste, who had qualified as an accountant at Stellenbosch University, was smart, cunning and entrepreneurial. Rather than serve in the army in the mid 1980s, he chose to work at SARS where he evidently developed a keen sense of just how flexible the tax rules could be. Jooste stitched his company, lounge suite maker GommaGomma, together with Bruno's European furniture company, and listed it on the JSE in 1998. "To go to the stock market was absolutely new for me", said Bruno. "I never learned that - I was never in a high school, I was always in my personal high school, learning everything by doing" (Steinhoff, 2018).

Steinhoff, with Jooste as the CEO, began to expand. At home, it hoovered-up logistics company Unitrans, timber company PG Bison, manufacturing company KAP and JD Group, which owned consumer brands like Joshua Doore, Hi-Fi Corporation and Incredible Connection. But Jooste also began expanding overseas, buying Homestyle in the UK (2005), Freedom Group in Australia (2005) and Conforama in Europe (2011). 
In fact, by 2013, it had become the second-largest furniture retailer in Europe, trailing only the iconic Swedish chain Ikea. In 2014, Jooste added discount clothing chain Pep to Steinhoff's portfolio - a blockbuster R63bn deal that had the added attraction of enticing Pep's largest shareholder, South Africa's richest man, Christo Wiese, into the Steinhoff stable.

Andrew Cuffe, the former head of research at JP Morgan, says the Pepkor deal was a turning point for Steinhoff, establishing them as a serious contender in South Africa's investment world. "If some considered them the Mafia until that point, perhaps that deal was Steinhoff's way of going straight - like buying some legit dry-cleaners", maintains Cuffe (2018).

Quite how bent Steinhoff was would only become clear sometime later. But as it was, even back in 2014, the clouds soon began to gather as whispers of accounting hi-jinks gathered steam. A year later, December 2015, was meant to be a triumphant homecoming for Bruno Steinhoff. The company planned to list its shares on the Frankfurt Stock Exchange, becoming Germany's largest stock exchange listing that year. It took place to much fanfare - flashmobs of dancers outside the exchange, accompanied by glitzy banners. Only, the weekend before that listing, German police had arrived in Westerstede, and conducted an extensive raid on the business. "There are suspicions that sales are overstated in the balance sheet," the prosecutors said. Accounting irregularities, in other words (Rose, 2015).

Wiese, by now Chairman, went on radio calling the allegations "drivel". Nothing to see here, no crime has been committed.

Fast forward to December 5th 2017: Steinhoff releases a statement, saying Marcus Jooste has "resigned with immediate effect", and the company now believes that actually, yes there were indeed "accounting irregularities" (Steinhoff International Holdings NV, 2017). This, in the end, turned out to be a whopping euphemism. Indeed, the extent of quite how corrupt the company was astounded even the most sceptical of Jooste-cynics.

In the end, forensic accountants established, Steinhoff's profits had been artificially boosted by R106bn in "fictitious or irregular" profits over the course of a decade. This was, in other words, money that just did not exist (Steinhoff International Holdings NV, 2019). It was terrifying in its audacity: fake cash flows, "buying groups" that supposedly provided discounts, but which actually did not exist, and secretive deals designed to enrich Jooste and his inner circle. The scale of it dwarfed any other South African fraud. That includes those involving Brett Kebble (R56bn, adjusted for inflation, in today's money), Masterbond (R4.1bn), LeisureNet (R2.4bn), Fidentia (R2.2bn) or, more recently, VBS Mutual Bank (R2bn). 
Heather Sonn, the former investment banker who replaced Wiese as Steinhoff's Chair, has likened the scale of it to Enron - the Houston-based energy company that went bankrupt in 2001. Like Enron, she says, "there was purposeful deceit where certain people went to great lengths to misrepresent the financial statements, in collusion with others" (Rose, 2018b).

It is similar, too, in that both Enron and Steinhoff had been amongst the largest 40 stocks listed on the US and South African stock exchanges respectively; and in both cases, a large cross section of their country's pensioners were exposed to the collapsing companies. In SA, the regulator, the Financial Sector Conduct Authority (FSCA), told Parliament in January 2018 that $87 \%$ of pension funds surveyed at the time had exposure to Steinhoff and had lost billions as a result (Ensor, 2018). It is an important point: this wasn not just a minor fracas taking place on the fringes of society affecting only stock market traders; it was a fraud that had an actual impact on the retirement savings of South Africa's working population. And, ultimately, on the decisions by foreign companies to invest in the country.

\subsection{A SLIPPERY SLOPE}

It is an arresting picture. But what is more alarming, and suggestive of a systemic problem, is that Steinhoff was just one of a number of former blue-chip South African companies to suffer a governance crisis in recent years. Down in Umhlanga, on KwaZulu-Natal's north coast, the province's largest employer Tongaat Hulett has been battling an "accounting scandal" of its own. In that case, it was not "fake buying groups", or complicated German guarantees. Tongaat, battling a 25\% collapse in the global price of sugar from 2015 to 2018 , began looking for accounting "short cuts" to fill its profit hole, hoping that the cycle would turn back.

Here is an example of one such short cut, indicative of a badly misfiring ethical compass. As you would expect, a sugar company's main assets are the land it farms on, and its sugar cane. So Tongaat began selling land at a furious clip to plug the hole in its profit. But when the ANC government began talking about "expropriation without compensation" in 2018, buyers became understandably more reluctant to sign the documents. Tongaat, however, could not afford delays. So, as forensic investigator PwC concluded in November 2019 after spending months decoding the scandal, Tongaat had "backdated ... a number of land sale agreements" to push through the deals (Tongaat Hulett Limited, 2019).

This was not the only schlenter. When it came to its sugar cane, Tongaat pushed up the value of these plants radically, allowing it to claim higher assets and profits than was really the case. So, over nine years to 2018, the value of Tongaat's "standing sugar cane" in South Africa soared 580\% to R764m, while the value of its roots more than 
doubled. It meant that Tongaat valued its sugar cane roots at R27 869 per hectare more than double what you would see at rivals like Illovo Sugar (Rose, 2019).

Why do this, you ask? So that Tongaat could include these "revaluations" in its profit numbers, convincing investors it was doing better than it was. In 2018, for example, of the R86m operating profit reported by Tongaat's sugar division, no less than $\mathrm{R} 57 \mathrm{~m}$ came from "revaluing cane upwards". It was a short-cut. As Tongaat's new CEO Gavin Hudson, who took over last February, puts it: "Hope is the key word. Believing that things will turn and that tomorrow will somehow be greener and brighter has been the underlying view of this business for years" (Rose, 2019).

Only, it just got worse. A drought, a glut of imported sugar, and problems in Zimbabwe meant that it was never able to climb out of the hole. However, when this author tracked down the former CEO Peter Staude, who has been at the helm from 2002 until he resigned in August 2018, his response suggested an alarming moral relativism.

First, he admitted that in recent years, "we needed to pick up the pace of sales from land conversion (and) there's no doubt that we used year-end deadlines to get the other parties involved over the line," he says. But he seemed remarkably unconcerned over the "backdating" of land deals. Staude's response: "all backdating might mean is that you've done a deal, but finalising the paperwork needs to be concluded".

The forensic auditors took another view, however. As a result, Tongaat laid criminal charges against the Executives responsible for backdating these deals. This would seem to be another example of the blithe lack of concern for the rules, which Katz described earlier.

There is another grim example, technology company EOH. Between 1998 and 2015, it was the best performing tech company on the stock exchange: a R10 000 investment would have turned into R640 000. It was also the country's largest technology company, servicing 2000 large companies. But there was a major caveat: it got to this position by either buying smaller rivals or doing business with people it should not have.

Here is one example: in November 2015, EOH forked out R868m to buy three companies, Grid Control Technologies, Forensic Data Analysts and Investigative Software Solutions, owned by a former policeman named Keith Keating (Ziady, 2017). Clearly, EOH had not done its homework into quite how Keating makes his money. It emerged that for seven years from 2010, Keating's companies scored R5.4bn in contracts from the SA Police Service (SAPS) and the State IT Agency (SITA) to supply equipment, like cameras and torches (Rose, 2017). A report by the Independent Police Investigating Directorate (IPID) in October 2015 said those contracts were the fruits of a "corrupt relationship" between Keating and former police commissioner, Khomotso Phahlane. 
Consider what the police bought: crime scene torches for R300 000 each (which you could pick up for R7000), R129 for each pair of latex gloves (which you could buy at a pharmacy for R1), disposable face masks for R1 000 each, and distilled water for R1.6m (Hosken, 2017). As a quid-pro quo, Keating allegedly paid R1m to a car dealer for a number of vehicles, including a Toyota Hilux bakkie, Hyundai i20, Ford Ranger and Volkswagen Polo for Phahlane, his wife, daughter and sister. Helpfully, they were invoiced to "Joe Doe" (Hosken, 2017) (Phahlane was later arrested for procurement fraud, though apparently this was an unrelated case).

There were many other problems at $\mathrm{EOH}$, but this is just a sample of the flavour of what went wrong. In September 2018, a banker from Absa, Stephen van Coller, was appointed $\mathrm{CEO}$ of EOH to fix it up. Speaking more than a year later, Van Coller says that one of the lessons he learned is that corruption had been "normalised" at the company. "If you don't have a culture of doing the right things, in the right way, with the right customers, you're finished," he wrote (Van Coller, 2020).

Mirroring the wider political environment, accountability at $\mathrm{EOH}$ was poor. There was, Van Coller pointed out, only one compliance officer for the whole company, spanning more than 500 businesses. As Van Coller put it: "suddenly you're doing 10-15 tenders a week and you can't look at every single one and make sure everything is perfect, so you start cutting corners. Cutting a corner becomes the new norm, because you can't keep up" (Talevi, 2019).

\subsection{COINCIDENCE, OR A REFLECTION OF THE SOCIAL FABRIC?}

Cutting corners, clearly, was not just the preserve of $\mathrm{EOH}$. The question is, was there a golden thread linking all these scandals together?

Firstly, just to get the obvious point out of the way: South Africa's economic collapse during the Zuma years wedged many companies into a corner. Had the economy been booming, either the CEOs might not have been tempted to sweeten reality, or their crooked activities might not have been detected. Still, it seems remarkable that all these scandals - each of them precedent-setting in the South African context emerged over a two-year period at the end of Jacob Zuma's presidency. It could, of course, just be a coincidence. But it seems unlikely.

Nicky Newton-King, who headed the JSE during the state capture years until she retired in October 2019, says the prevailing lack of accountability in government during those years dominoed into the private sector. "Once the fish rots from the head, and once there's no visible accountability on even the small things, it's easier for moral compasses to wobble," she says (Newton-King, 2019). And now, she maintains, there's a definite sense that the country's private sector needs to reset that ethical compass. 
Still, it has been a bracing realisation that many of the comforting assumptions we had about the strength of the corporate sector - particularly, that it was somehow more 'ethical' than the public sector - were simply wrong. Newton-King argues: "we imagined that we lived in a regulatory regime, which was stable and robust, where people were held to account. Now, we don't think that anymore. When the tide went out, people in various industries were caught out" (Newton-King, 2019).

The truth was those who believed the private sector was ethically unimpeachable were simply fooling themselves. For a country that had complacently believed it was top dog in governance and regulation, these scandals were like a bucket of ice water.

Until 2016, the (admittedly faulty) World Economic Forum competitiveness survey had ranked South Africa top of 138 countries when it came to "strength of auditing and reporting standards". Its corporate Boards were ranked third in the world too as was the regulation of our stock report (Schwab, 2016). By 2019, South Africa had sunk to 51st of 141 countries when it came to auditing standards, and 26th overall for corporate governance (Schwab, 2019). Asief Mohamed, the CEO of Aeon Investment Management, says there has been a problematic corporate culture going far back, to the years of apartheid. "Before 1994, we had very little competition in our industries, and our guys thought they were fantastic. Then, with some exceptions, like Discovery and SA Breweries, our guys went overseas and discovered they weren't as good as they thought they were," he says (Mohamed, 2019).

For Mohamed, the collapses at Steinhoff, Tongaat and EOH show that our Boards of directors - the forum for accountability and oversight in the corporate sector have not really improved over the years. And, as a result, these Boards are chronically unable to hold people to account. "In the case of Steinhoff, you had unmitigated greed of a few individuals, with an utter lack of accountability. The Board was fast asleep, and it's the same thing we've seen elsewhere too, like at Tongaat Hulett," he tells (Mohamed, 2019).

Perhaps the most remarkable thing about Steinhoff is that, on paper, it was the best equipped Board in the country. It had three directors on its Board with $\mathrm{PhDs}$ in accounting - Dr Len Konar, Steve Booysen and Theunie Lategan - and yet, it had the worst accounting scandal in South African history. Another, former Sanlam CEO Dr Johan van Zyl, had a PhD in economics into the bargain. Members of Steinhoff's Board dispute the view that they were napping, however. They argue no one could have detected an ingenious, deliberate and complicated fraud. Konar, for example, said: "[W]e were misled, we were lied to. We asked for information and either it was not forthcoming, or [it was] presented in a way that wasn't representative of the truth" (Rose, 2018a). 
Johan van Zyl, however, admits that the Board could have been more vociferous in probing individual deals done by Jooste. "We could have interrogated the purchases of things like Mattress Firm more, perhaps" (Van Zyl, 2018). And he adds that far too many Board Members had entrenched relationships with Jooste, as they had been on Steinhoff's Board for many years. "So, it perhaps wasn't as independent as it should have been," he says.

\subsection{WATCHDOGS WHO DIDN'T BARK}

If the state capture era was notable for the failure of accountability, and efforts by rent-seekers to weaken institutions of accountability, it is instructive to look at what happened to the watchdogs in the private sector. This includes Boards of Directors, regulators, pension fund trustees, investment companies and analysts. But perhaps the most trusted of all these "guardians of governance" were South Africa's audit companies. Those auditors are, after all, the ones who sign at the bottom of each set of financials that the numbers "fairly represent" the position of the company.

It is clear Steinhoff's financial statements, which allowed R106bn of fictitious profits to creep in, should not have carried the signature of its auditor, Deloitte. Neither should Tongaat's financials, also audited by Deloitte.

Look wider and there are many such cases. Take Eskom, where SizweNtsalubaGobodo (SNG) have been auditors since 2012 (alongside KPMG for two of those years) and should have known what was going on. And yet, Eskom racked up R19.6bn in "irregular expenditure" between 2012 and 2018. As Public Enterprises Minister Pravin Gordhan pointedly asked when Eskom's financials for 2018 were released: "where were the auditors when these corrupt acts were going on?" (Steyn, 2018) (SNG, who was also auditors to state entities Transnet and Denel, has since merged with the larger Grant Thornton to become SNG Grant Thornton).

Perhaps the audit firm that has most reaped the state capture whirlwind is KPMG, the multinational auditor with officers in 154 countries which traces its South African roots to 1895, when the Scottish-born Alexander Aiken opened an office in Johannesburg. KPMG had been the auditors to the Gupta companies for 15 years, something the family had proudly trumpeted as evidence of its legitimacy. In the end, it was the audit of the Guptas' company Linkway Trading in 2014 that led to KPMG coming unstuck.

It turned out that Linkway was used as a conduit for many of the expenses for the notorious Gupta wedding held at Sun City, which four KPMG partners attended (Marriage, 2019). Here, KPMG's partner Jacques Wessels signed-off Linkway's accounts, which deducted the R6.9m in wedding costs from its tax liability, classifying 
it as a "business expense". For this, Wessels was struck off the register of auditors by the Independent Regulatory Board for Auditors (IRBA). "There was no evidence that he had applied professional scepticism or that the threats to objectivity were identified or considered", IRBA (2019) said.

It was a damaging ruling, especially as it came shortly after KPMG had apologised for work its consulting arm had done for SARS, which concluded that a "rogue unit" had operated within. This finding allowed a new Commissioner close to Zuma, Tom Moyane, to oust several veteran tax officials.

But the biggest scandal was yet to come: in October 2018, a Reserve Bank investigation into the collapse of a small bank in Limpopo, VBS Mutual Bank, concluded that KPMG's senior banking partner, Sipho Malaba, had intentionally lied, covering up the theft of more than R2bn from the bank (Motau, 2018). It was a deceit aimed at some of South Africa's most vulnerable citizens. VBS is situated in one of South Africa's poorest province Limpopo, where $43.9 \%$ of citizens, at the widest definition, do not have jobs (Stats SA, 2019).

As it was, VBS' accounts were an elaborate fairy tale: almost R2bn had been stolen, covered up with "phantom deposits"; while the R770m in cash reported for 2017, was "in truth overstated by approximately R700m". VBS's Executives had behaved with impunity, as if they were feudal kings whom bank depositors were obligated to support. The bank's CEO, Robert Madzonga, spirited away enough cash to pay off six cars (worth more than R6m), cover his R213000 monthly mortgage, and pay for lavish seafood dinners. Evidence given to the Reserve Bank's investigator, advocate Terry Motau, illustrated clearly how Malaba, who was KPMG's senior banking partner in the county, was central to this heist.

Consider the evidence of Zondi Ntuli, a trainee auditor. Ntuli described how, when he was helping prepare VBS's accounts in July 2017, nothing seemed to add up. So, he called the other KPMG audit manager on the VBS audit, Kafuma Munalula. "Look, Kafuma, there is cash missing here, because none of this is stacking up," he said. Munalula said she would get "Sipho to look at it". But when she asked him, he simply brushed her off. "He told me that he was handling it," she says.

Nonetheless, Munalula wrote a report to the audit committee, which pointed out that "not all bank reconciliations have been received". However, Malaba took that draft, and in a green marker, scratched out her words. Later, when she asked him again if he was happy with the cash number, Malaba replied by SMS: "Yes, happy to go ahead". The next thing, Malaba had simply signed off VBS' accounts, where almost all the reported cash was missing. 
Why would he do this, you ask? Was it just naivety? Incompetence? In reality, the answer was much more sinister.

As it turns out, VBS had not only given Malaba a R7.3m mortgage bond for a house in Fourways, the bank had also given him an R20m overdraft, and had financed the purchase of several cars, including a Range Rover, Landrover Discovery and a Mercedes Benz. Remarkably, he had never paid a cent of these loans. Nor, in fact, had VBS even tried to recover any of the money. When asked by Motau, why he had not repaid anything, Malaba said he was "over-stretched". And the zinger was that Malaba has also hidden all the details of his loans from KPMG (Motau, 2018).

It is a damning picture. In the end, Motau concluded that Malaba was "indeed complicit in the cover-up of the vast cash hole in VBS ... by signing a fraudulent audit report". He concluded that Malaba had "deliberately disguised the fact that he was the beneficiary of the various facilities" and "when KPMG made an enquiry about his facilities at VBS he obtained a fraudulent letter from VBS to put KPMG off the scent"(Motau, 2018).

While the Gupta audit of Linkway was poor, KPMG's complicity in the VBS fraud is on another level entirely. Auditors often make errors, like at Steinhoff or Tongaat. But intentional corruption? That is a step change.

Unlike Steinhoff or the other cases, KPMG did not fail to detect the fraud at VBS - it did pick up that hundreds of millions of rand was missing. It is just that the senior partner in charge had been compromised.

KPMG later said it would "support criminal action" against Malaba who resigned in April 2018, facing a disciplinary inquiry for not declaring his financial interest at VBS (Dlula, 2018).

It caused tremors across the globe. The Financial Times, for example, reported the views of economist Iraj Abedian who said:"increasingly it is becoming self-evident that KPMG is not fit to be in business - never mind being a 'major audit firm"' (Marriage, 2018). The taint of state capture hung heavy over KPMG and, predictably, it lost about a third of its R3bn in revenue between 2017 and 2019, as both clients and partners fled (Henderson, 2019).

Today, Ignatius Sehoole, the CEO of KPMG South Africa, says the firm's efforts to fix its culture - including putting partners and their spouses through lifestyle audits - are paying off. Clients are returning, he says, and there is a renewed interest in working at KPMG. Asked why the VBS debacle happened in the first place, Sehoole attributes this partly to the country's ethical culture during the state capture years. "We often talk glibly about the 'tone at the top', but it's a real thing. If you see politicians feeding 
from the trough all the time, the temptation is there to think, 'why can't I be part of that too'," he says (Sehoole, 2019).

\subsection{BRIDGING THE 'EXPECTATION GAP'}

Audit firms are aware of the public perception that they not only failed to red-flag state capture, but that they actually aided it. Many of them are now going through deep internal angst about the "expectation gap" between what the public wants of them, and what they actually do. "It's clear that some people believe auditors are meant to detect fraud when this is not the focus of an audit. But we need to address this gap, as best we can, if we want to restore trust," says Lwazi Bam, CEO of Deloitte Southern Africa. Bam says, rightly, that a "fundamental recalibration is needed to reposition the audit product as a synonym for trust" (Bam, 2019).

Quite how successful that will be depends on whether the scandals keep on coming. It does not help Deloitte's case, for example, that in early 2020, revelations emerged of how Eskom is seeking to recover R207m from it for consulting contracts awarded it by the power utility in 2016 (Comrie, 2020). But Bam's message - that auditors need to win the public's trust again - is on point. To do so, they need to ensure every decision is ethically unimpeachable.

Which it has not been to date. Auditors bending over backwards to hide wedding expenses for his client or looking the other way as a bank is robbed blind because he is getting effectively paid-off, does deep structural damage to the profession. If state capture is about repurposing institutions to fit the will of venal rent-seekers, it does not help that the auditors who are at the front-line, and who could blow the whistle, instead displayed an alarming moral agnosticism. At worst, cynics would argue that their professional opinion was for hire to the highest bidder.

South Africa's auditors are not an island, of course. Globally similar questions are being asked about the profession in other countries. In the UK, EY came under fire for its flawed audit of collapsed travel company Thomas Cook, while a British Parliamentary report found KPMG failed to exercise "professional scepticism" at construction company Carillion (House of Commons, 2018). And in India, the government actually sought a five-year ban for KPMG and Deloitte for allegedly "actively conniving" to hide bad loans at construction firm Infrastructure Leasing \& Financial Services (Vyas \& Dave, 2019).

Across the globe, the industry was in need of an overhaul, and into the breach stepped Sir Donald Brydon, the former Chair of the London Stock Exchange (LSE). In 2019, Brydon concluded a 10-month investigation into the quality of $\mathrm{UK}$ audits. His report, released last December, was highly critical. On the "expectation gap", Brydon suggested 
the problem was wider than simply a disconnect with the public - it was more that auditors just are not doing their jobs thoroughly anymore. As one submission to him succinctly put it: "the problem is not one of expectations, rather we have a grave 'delivery gap' when it comes to audit," he said (Brydon, 2019).

It is a sentiment that most people in South Africa would agree with. To simply dismiss the concerns about auditing standards under the rubric of an "expectation gap" fails to account for just how dismally they actually perform their core job. Critically, Brydon stressed the need for auditors to realise they perform a "public interest" function, and he suggested the UK's rules be changed to "make clear that it is the obligation of an auditor to endeavour to detect material fraud in all reasonable ways" (Brydon, 2019).

It is a revolutionary suggestion which, if it were implemented in South Africa, would change the game for auditors. South Africa, of course, is not obliged to follow Brydon's lead, but many senior auditors believe the country is likely to do so. Had there been a heightened requirement to detect fraud, perhaps VBS, Steinhoff and Tongaat may never have happened. And the repurposing of Eskom and Transnet to suit the state capturers would not have passed 'go'.

\subsection{WANTED: CEOS IN JUMPSUITS}

It is clear that auditors, and the watchdogs meant to ensure the corporate sector behave properly, went missing when they were most needed. They became part of the general malaise of a lack of accountability in South Africa. But the introspection since the scandals of Eskom, Steinhoff and VBS - of how Boards of Directors, auditors and regulators operate - may yet be a catalyst for a fundamental shake-up in behaviour.

For Michael Katz, the tide could shift very quickly to restore trust in accountability in the corporate sector. "I met Shamila Batohi, the Director of Public Prosecutions, and I told her that all we need is just one arrest, and one prosecution - and it'll have a meaningful impact. From day one, there'll be a material change, as it will signal that the days of acting with impunity and without consequence are over," he says (Michael Katz, 2019).

Quite why no one has been arrested at Steinhoff, considering there is a forensic report running to more than 3000 pages (15000 with annexes) detailing exactly who did what is a mystery. The Hawks, supposedly South Africa's priority crime unit, have access to parts of that dossier, yet have not acted. Markus Jooste still goes for a stroll on the Hermanus cliff walks; those who stole R2.1bn from EOH act as if nothing happened; and the VBS masterminds are jetting around in their luxury cars.

Of course, it would be supremely naive to imagine the criminal authorities were shining examples of speed and action before Jacob Zuma took charge. 
Take the case of Tigon, and Gary Porritt. Tigon was once one of the top 40 stocks on the JSE, but in 2002, Porritt and his co-Director Sue Bennett were arrested and charged on 3160 counts of fraud (Groenewald, 2018). But as it stands today, Porritt and Bennett have been running rings around first the NPA, and then the judiciary. They are, in theory, "standing trial" in the South Gauteng High Court, 17 years later (Mabuza, 2020). But you would be a brave man to bet they would be sentenced anytime soon.

Batohi is, however, apparently determined to act on Steinhoff. "There have been proposals by the joint team - the investigators and the prosecutors - about certain steps that can be taken in the shorter term," she said in October 2019 (Gerber, 2019).

Reintroducing accountability could not come a moment too soon. Using Katz's hierarchy, had the crooked Executives believed there was any chance of detection and apprehension, they might not have broken the rules in the first place. 


\section{References}

Bam, L. (2019) 'The battle to restore trust in auditing, Financial Mail. [Online]. https:// bit.ly/3yxs $1 U z$ (Accessed 27 January 2020).

Brydon, D. (2019) 'Report of the Independent Review into the Quality and Effectiveness of Audit', UK Government. London. [Online]. https://bit.ly/2Vp0BCh (Accessed 27 January 2020).

Comrie, S. (2020) 'The dirt on Deloitte's consulting deals at Eskom, Part 1', amaBhungane. [Online]. https://bit.ly/ 2VDUCJz (Accessed 27 January 2020).

Cuffe, A. (2018) Author's interview with Andrew Cuffe, August.

Dlula, N. (2018) 'South Africa’s KPMG reports ex-partner to police over bank scandal', Reuters. [Online]. https://reut.rs/3lH4Nbi (Accessed 27 January 2020).

Ensor, L. (2018) 'Pension funds lost billions over Steinhoff', Business Day. [Online]. https://bit.ly/3jwqWX5 (Accessed 27 January 2020).

Gerber, J. (2019) 'Steinhoff: To go for lowhanging fruit or big fish, asks Batohi', News24. [Online]. https://bit.ly/2U2WP0E (Accessed 27 January 2020).

Groenewald, Y. (2018) 'Marathon fraudster trial stutters on', Fin24. [Online]. https://bit.ly/ 37rNouM (Accessed 27 January 2020).

Henderson, R. (2019) 'KPMG South Africa winning back customers as reputation recovers, says CEO', Fin24. [Online]. https:// bit.ly/3xpfelW (Accessed 27 January 2020).

Hosken, G. (2017) 'Top cop 'on a tender bender”, Times Live. [Online]. https://bit.ly/3xuBcnB (Accessed 27 January 2020).

House of Commons (2018) 'House of Commons: Business, Energy and Industrial Strategy and Work and Pensions Committees report on Carillion', www.parliament.uk. [Online].https://bitly/3AhmQbW (Accessed 27 January 2020).

Independent Regulatory Board for Auditors (IRBA) (2019) Linkway Trading auditor deregistered - ordered to contribute to costs. [Online]. https://bit.ly/3AlmYHC (Accessed 27 January 2020).
Mabuza, E. (2020) 'SA courts to grapple with Jacob Zuma and Gary Porritt cases in 2020, Business Day. [Online]. https://bit.ly/ 3CoS8zA (Accessed 27 January 2020).

Marriage, M. (2018) 'KPMG under fresh attack in South Africa over 'great bank heist", The Financial Times. [Online]. https://on.ft.com/ 2X4YCDz (Accessed 27 January 2020).

Marriage, M. (2019) 'Former KPMG partner struck off South Africa register over Gupta audits', The Financial Times. [Online]. https://on.ft.com/3Cu9Y4m (Accessed 27 January 2020).

Michael Katz (2019) Author's interview with Michael Katz, July.

Mohamed, A. (2019) Author's interview with Asief Mohamed, October.

Motau, T. (2018) 'VBS Mutual Bank - The Great Bank Heist: Investigator's Report to the Prudential Authority', South African Reserve Bank. Johannesburg: Werksmans Attorneys. [Online].https://bit.ly/3AkDHe1(Accessed 12 October 2018).

Newton-King, N. (2019) Author's interview with Nicky Newton-King, October.

Rose, R. (2015) 'Steinhoff's tax headache', Financial Mail. [Online]. https://bit.ly/ 3AfaWPM (Accessed 27 January 2020).

Rose, R. (2017) 'The Trouble with EOH', Financial Mail. [Online]. https://bit.ly/ 3CnpYox (Accessed 27 January 2020).

Rose, R. (2018a) 'EXCLUSIVE: We were bamboozled, say Steinhoff directors', Financial Mail. [Online]. https://bit.ly/ 3Ajwyun (Accessed 27 January 2020).

Rose, R. (2018b) 'Inside SA's Enron: Deconstructing Steinhoff', Financial Mail. [Online]. https://bit.ly/3iuDRJO (Accessed 17 September 2020).

Rose, R. (2019) 'EXCLUSIVE: New Tongaat $\mathrm{CEO}$ on what went wrong at sugar giant', Financial Mail. [Online]. https://bit.ly/ 2VGCWgs (Accessed 27 January 2020).

Schwab, K. (2016) 'Insight Report: The Global Competitiveness Report 2016-2017', World Economic Forum. https://bit.ly/3CoauRh (Accessed 27 January 2020). 
Schwab, K. (2019) 'Insight Report: The Global Competitiveness Report 2019', World Economic Forum. [Online]. https://bit.ly/ 31CALW0 (Accessed 27 January 2020).

Sehoole, I. (2019) Author's interview with Ignatius Sehoole, December.

Stats SA (2019) Quarterly Labour Force Survey Quarter 3: 2019. [Online]. https://bit.ly/ $37 \mathrm{ggOcB}$ (Accessed 27 January 2020).

Steinhoff, B. (2018) Author's interview with Bruno Steinhoff, May.

Steinhoff International Holdings NV (2017) Steinhoff Announces Investigation into Accounting Irregularities and Resignation of CEO (6 December 2017). [Online]. https:// bit.ly/3julqEh (Accessed 27 January 2020).

Steinhoff International Holdings NV (2019) Overview of Forensic Investigation (15 March 2019). [Online]. https://bit.ly/ 3AkEIml (Accessed 27 January 2020).

Steyn, L. (2018) 'Did auditors turn blind eye at Eskom?', Business Day. [Online]. https://bit. ly/2Vp68cl (Accessed 27 January 2020).

Talevi, G. (2019) 'CEO Stephen van Coller tackles EOH fallout', Financial Mail. [Online].
https://bit.ly/31DLSOX (Accessed 27 January 2020).

Tongaat Hulett Limited (2019) Key findings of PwC investigation. [Online]. https://bitly/ 3yuMLwg (Accessed 27 January 2020).

UNCTAD (2019) UNCTAD: Country Fact Sheets 2019, United Nations Conference on Trade and Development (UNCTAD). [Online]. https://bit.ly/3iwxDcq (Accessed 27 January 2020).

Van Coller, S. (2020) 'What I learnt from EOH about preventing corruption', Daily Maverick. [Online]. https://bit.ly/3rZJIPD (Accessed 27 January 2020).

Van Zyl, J. (2018) Author's interview with Johan van Zyl.

Vyas, M. \& Dave, S. (2019) 'Deloitte, KPMG firms get time till Friday to argue against ban plea, The Economic Times. [Online]. https://bitly/2U5Rbeg (Accessed 27 January 2020).

Ziady, H. (2017) 'The puzzle of EOH's share collapse', Financial Mail. [Online]. https:// bit.ly/2TYrKeo (Accessed 27 January 2020). 



\section{APPENDIX}

\begin{tabular}{|c|c|c|c|c|}
\hline $\begin{array}{l}\text { Case Study } \\
\text { in State } \\
\text { Capture }\end{array}$ & Status & Summary Description & $\begin{array}{l}\text { Investigation } \\
\text { Body / } \\
\text { Source of } \\
\text { Evidence }\end{array}$ & $\begin{array}{l}\text { Government } \\
\text { Entity } \\
\text { Implicated }\end{array}$ \\
\hline \multicolumn{5}{|c|}{ Scandals Connected to Jacob Zuma, Guptas, Other Key Networks and ANC Politics } \\
\hline $\begin{array}{l}\text { The State } \\
\text { of Capture } \\
\text { report- } \\
\text { focuses } \\
\text { on Guptas' } \\
\text { relationship } \\
\text { with Jacob } \\
\text { Zuma and } \\
\text { their alleged } \\
\text { influence on } \\
\text { the affairs } \\
\text { of state }\end{array}$ & $\begin{array}{l}\text { First complaint } \\
\text { was received } \\
\text { in March } 2016 \\
\text { and the report } \\
\text { was released in } \\
\text { November } 2016 .\end{array}$ & $\begin{array}{l}\text { Investigation into complaints of alleged improper } \\
\text { and unethical conduct by the President and } \\
\text { other State Functionaries, relating to alleged } \\
\text { improper relationships and involvement of the } \\
\text { Gupta Family in the removal and appointment } \\
\text { of Ministers and Directors of State-Owned } \\
\text { Enterprises (SOEs), resulting in improper and } \\
\text { possibly corrupt award of State Contracts and } \\
\text { Benefits to the Gupta Family's Businesses. } \\
\text { The report details numerous allegations of } \\
\text { the Guptas' involvement in affairs of the state } \\
\text { and their irregular activities that enable rent } \\
\text { extraction. The findings were not conclusive } \\
\text { and the remedial action was to establish a } \\
\text { commission of inquiry into state capture (to } \\
\text { be appointed by the President, but with a } \\
\text { judge selected by the Chief Justice). Litigation } \\
\text { endeavoured to delay or prohibit the report's } \\
\text { release and implementation of remedial actions, } \\
\text { but failed, and the commission was established } \\
\text { in } 2018 \text {. }\end{array}$ & $\begin{array}{l}\text { - Public } \\
\text { Protector, } \\
\text { followed by } \\
\text { litigation }\end{array}$ & $\begin{array}{l}\text { - GCIS (The } \\
\text { New Age) } \\
\text { - Eskom } \\
\text { (Optimum) } \\
\text { - Transnet } \\
\text { (Regiments/ } \\
\text { Trillian) } \\
\text { - Denel } \\
\text { - SAA (The } \\
\text { New Age) } \\
\text { - SABC (The } \\
\text { New Age) } \\
\text { - Department of } \\
\text { Finance } \\
\text { - Transport } \\
\text { (SAA) } \\
\text { - Communica- } \\
\text { tions (SABC } \\
\text { \& GCIS) }\end{array}$ \\
\hline $\begin{array}{l}\text { Zondo } \\
\text { Commission }\end{array}$ & $\begin{array}{l}\text { Established } \\
\text { in 2018, with } \\
\text { anticipated } \\
\text { conclusion being } \\
\text { the end of } 2021 .\end{array}$ & $\begin{array}{l}\text { Formally titled the Judicial Commission of } \\
\text { Inquiry into Allegations of State Capture, } \\
\text { Corruption and Fraud in the Public Sector } \\
\text { including Organs of State, the Commission } \\
\text { was promulgated by then President Zuma in } \\
\text { response to the remedial actions as outlined in } \\
\text { the Public Protector's State of Capture report. } \\
\text { As of June } 2021 \text {, the Commission that started } \\
\text { in August } 2018 \text { has held more than } 418 \text { days } \\
\text { of hearings of over } 330 \text { testimonies (generating } \\
\text { over } 71000 \text { pages of transcript). The inquiry's } \\
\text { terms of reference were expansive and, as } \\
\text { such, the scope of investigations went beyond } \\
\text { merely looking into the Gupta-related cases, } \\
\text { covering other networks (e.g., Bosasa) as well } \\
\text { as other government institutions (e.g., role } \\
\text { of Parliament). }\end{array}$ & $\begin{array}{l}\text { - Zondo } \\
\text { Commission }\end{array}$ & $\begin{array}{l}\text { Various } \\
\text { work-streams } \\
\text { covering } \\
\text { inter alia: } \\
\text { - SOEs } \\
\text { (Eskom, } \\
\text { Transnet, } \\
\text { Denel, SAA) } \\
\text { - Free State } \\
\quad \text { Provincial } \\
\text { Government } \\
\text { - Bosasa } \\
\text { - SARS } \\
\text { - Law } \\
\text { enforcement } \\
\text { - State Security } \\
\text { Agency (SSA) } \\
\text { - The New Age } \\
\text { \& ANN7 } \\
\text { - Role of } \\
\text { Parliament } \\
\text { and ANC }\end{array}$ \\
\hline
\end{tabular}




\begin{tabular}{|c|c|c|c|c|}
\hline $\begin{array}{l}\text { Case Study } \\
\text { in State } \\
\text { Capture }\end{array}$ & Status & Summary Description & $\begin{array}{l}\text { Investigation } \\
\text { Body / } \\
\text { Source of } \\
\text { Evidence }\end{array}$ & $\begin{array}{l}\text { Government } \\
\text { Entity } \\
\text { Implicated }\end{array}$ \\
\hline \multicolumn{5}{|c|}{ Scandals Connected to Jacob Zuma, Guptas, Other Key Networks and ANC Politics } \\
\hline Bosasa & $\begin{array}{l}\text { Dating back to a } \\
2009 \text { SIU report. } \\
\text { Investigations and } \\
\text { various litigations } \\
\text { are ongoing. }\end{array}$ & $\begin{array}{l}\text { In 2019, former Bosasa C00, Anglo Agrizzi, } \\
\text { testified at the Zondo Commission, detailing } \\
\text { the acts and long history of corruption between } \\
\text { various Bosasa companies predominantly } \\
\text { owned by Gavin Watson, and numerous } \\
\text { government entities/departments. The } \\
\text { testimony of Agrizzi (and other former Bosasa } \\
\text { employees) corroborated the findings of a } \\
2009 \text { SIU investigation that alleged corruption } \\
\text { in several contracts Bosasa had with the } \\
\text { Department of Correctional Services. Criminal } \\
\text { court proceedings have been initiated based } \\
\text { on the } 2009 \text { SIU investigation, along with new } \\
\text { investigations initiated by SARS and other law } \\
\text { enforcement entities. }\end{array}$ & $\begin{array}{l}\text { - Special } \\
\text { Investi- } \\
\text { gation } \\
\text { Unit (SIU) } \\
\text { - Zondo } \\
\text { Commission }\end{array}$ & $\begin{array}{l}\text { - Department of } \\
\text { Correctional } \\
\text { Services } \\
\text { - Department of } \\
\text { Justice } \\
\text { - Department of } \\
\text { Home Affairs } \\
\text { - Department of } \\
\text { Transport } \\
\text { - Various SOEs } \\
\text { (e.g., SAPO, } \\
\text { ACSA) } \\
\text { - National } \\
\text { Prosecuting } \\
\text { Authority } \\
\text { (NPA) } \\
\text { - Members of } \\
\text { Parliament }\end{array}$ \\
\hline Arms Deal & $\begin{array}{l}\text { Various } \\
\text { investigations and } \\
\text { sources, dating } \\
\text { back to 1990s. } \\
\text { Most significant } \\
\text { source being } \\
\text { through Seriti } \\
\text { Commission. } \\
\text { Corruption case } \\
\text { against Zuma is } \\
\text { ongoing. }\end{array}$ & $\begin{array}{l}\text { Commission of Inquiry into allegations of fraud, } \\
\text { corruption, impropriety, or irregularity in the } \\
\text { Strategic Defence Procurement Packages } \\
\text { (SDPP). Various court cases related to } \\
\text { allegations of corruption against Jacob Zuma. } \\
\text { On Monday, } 24 \text { October 2011, the President } \\
\text { announced the Commission chaired by Judge } \\
\text { Seriti. The findings of the Commission were that } \\
\text { there was "no evidence" of corruption, but this } \\
\text { is seen by many to have been a whitewash. The } \\
\text { report was taken on review and set aside in } \\
\text { August 2019. The corruption case against Zuma } \\
\text { is ongoing before the courts. }\end{array}$ & $\begin{array}{l}\text { - Seriti } \\
\text { Commission } \\
\text { - Various } \\
\text { court cases }\end{array}$ & $\begin{array}{l}\text { Initially: } \\
\text { - South African } \\
\text { National } \\
\text { Defence } \\
\text { Force } \\
\text { - Members of } \\
\text { Parliament } \\
\text { Allegations also } \\
\text { involve: } \\
\text { - NPA } \\
\text { - SSA }\end{array}$ \\
\hline $\begin{array}{l}\text { Nkandla } \\
\text { Security } \\
\text { Upgrades }\end{array}$ & $\begin{array}{l}\text { Investigation } \\
\text { started in } \\
\text { November } 2012 . \\
\text { Report on } \\
\text { investigation } \\
\text { was released in } \\
\text { March } 2014 .\end{array}$ & $\begin{array}{l}\text { Report on security upgrades to President } \\
\text { Zuma's homestead in Nkandla. The investigation } \\
\text { found that the President unduly benefited from } \\
\text { the upgrades and as part of remedial actions } \\
\text { the President was required to pay back a portion } \\
\text { of the costs of the upgrades. Zuma instructed } \\
\text { that SAPS undertake their own investigation, } \\
\text { which sought to rationalise the expenses (fire- } \\
\text { pool report). Parliament accepted this alternative } \\
\text { report, but major court cases followed, } \\
\text { ultimately declaring that the Public Protector's } \\
\text { remedial actions are binding. President and } \\
\text { Parliament failed to uphold the Constitution. } \\
\text { President ordered to "pay back the money". }\end{array}$ & $\begin{array}{l}\text { - Public } \\
\text { Protector's } \\
\text { Secured } \\
\text { in Comfort } \\
\text { report, } \\
\text { followed by } \\
\text { litigation }\end{array}$ & $\begin{array}{l}\text { - Department of } \\
\text { Public Works } \\
\text { - South African } \\
\text { Police Service }\end{array}$ \\
\hline
\end{tabular}




\begin{tabular}{|c|c|c|c|c|}
\hline $\begin{array}{l}\text { Case Study } \\
\text { in State } \\
\text { Capture }\end{array}$ & Status & Summary Description & $\begin{array}{l}\text { Investigation } \\
\text { Body / } \\
\text { Source of } \\
\text { Evidence }\end{array}$ & $\begin{array}{l}\text { Government } \\
\text { Entity } \\
\text { Implicated }\end{array}$ \\
\hline \multicolumn{5}{|c|}{ Scandals Connected to Jacob Zuma, Guptas, Other Key Networks and ANC Politics } \\
\hline $\begin{array}{l}\text { Private } \\
\text { Aircraft } \\
\text { Landing at } \\
\text { Waterkloof } \\
\text { Airforce Base } \\
\text { and Gupta } \\
\text { Sun City } \\
\text { Wedding }\end{array}$ & May 2013. & $\begin{array}{l}\text { In 2013, justice, crime prevention, and } \\
\text { security cluster (JCPS) - a cabinet structure } \\
\text { composed of various ministries - undertook an } \\
\text { investigation into the Landing of a Commercial } \\
\text { aircraft at Air Force Base Waterkloof (report } \\
\text { titled the same). The investigation revealed that } \\
\text { the Guptas initially tried to organise a special } \\
\text { landing at OR Tambo International Airport, but } \\
\text { was turned down. They then approached the } \\
\text { Indian High Commission who re-designated the } \\
\text { wedding entourage as an official delegation to } \\
\text { secure a landing at the Waterkloof base. The } \\
\text { wedding held at Sun City was attended by a } \\
\text { number of high-profile ANC politicians and was } \\
\text { paid for in part by moneys looted from the Vrede } \\
\text { Dairy Farm project. }\end{array}$ & $\begin{array}{l}\text { - Report by } \\
\text { JPCS } \\
\text { - Zondo } \\
\text { Commission } \\
\end{array}$ & \begin{tabular}{|l} 
- Department of \\
International \\
Relations and \\
Cooperation \\
(DIRCO) \\
- Department of \\
Defence \\
- Department of \\
Transport
\end{tabular} \\
\hline $\begin{array}{l}\text { Free State } \\
\text { Provincial } \\
\text { Capture, } \\
\text { includes } \\
\text { Vrede Dairy } \\
\text { Farm and } \\
\text { Asbestos } \\
\text { Contracts }\end{array}$ & Ongoing. & $\begin{array}{l}\text { The Vrede Dairy Farm project was initiated } \\
\text { by the Free State Provincial Government as a } \\
\text { development project, however, in partnering with } \\
\text { a Gupta-linked company Estina, government } \\
\text { funds were looted. In 2018, the Public } \\
\text { Protector released a report on their } 2018 \\
\text { investigation, but it was taken on review and } \\
\text { set aside by the courts. The second part of the } \\
\text { investigation is yet to be finalised. The NPA } \\
\text { laid criminal charges against Gupta associates } \\
\text { and implicated government officials. Court } \\
\text { proceedings are ongoing. } \\
\text { Significant testimony and evidence have been } \\
\text { presented at the Zondo Commission regarding } \\
\text { the Vrede Farm case, as well as the asbestos } \\
\text { inspection project (criminal proceedings are also } \\
\text { underway). Both projects implicate high-profile } \\
\text { politicians and senior officials manipulating } \\
\text { government process. }\end{array}$ & $\begin{array}{l}\text { - Public } \\
\text { Protector } \\
\text { reports } \\
\text { - Zondo } \\
\text { Commission } \\
\text { - Various } \\
\text { court cases } \\
\end{array}$ & $\begin{array}{l}\text { - Free State } \\
\text { Provincial } \\
\text { Government }\end{array}$ \\
\hline $\begin{array}{l}\text { Irregular } \\
\text { removal of } \\
\text { National } \\
\text { Director } \\
\text { of Public } \\
\text { Prosecutions } \\
\text { (NDPP), } \\
\text { Mxolisi } \\
\text { Nxasana }\end{array}$ & $\begin{array}{l}\text { Inquiry instituted } \\
\text { in February } 2015, \\
\text { but was cancelled } \\
\text { in May } 2015 . \\
\text { This triggers the } \\
\text { Constitutional Court } \\
\text { cases that followed. }\end{array}$ & $\begin{array}{l}\text { Inquiry into the fitness of Mxolisi Nxasana to } \\
\text { hold office as NDPP. The Inquiry was cancelled } \\
\text { after Zuma "agreed to let Nxasana resign". He } \\
\text { was paid R17m - the balance of his ten-year } \\
\text { contract. Court cases followed detailing the } \\
\text { abuse of the presidency powers by Zuma. } \\
\text { Ultimately, Nxasana was ordered to repay } \\
\text { R17m and Zuma's appointed replacement, } \\
\text { Shawn Abrahams, was ordered to vacate office. } \\
\text { Constitutional Court found Zuma's actions to } \\
\text { be an abuse of power and in breach of his } \\
\text { constitutional obligations. }\end{array}$ & $\begin{array}{l}\text { - Cassim } \\
\text { Inquiry into } \\
\text { fitness of } \\
\text { Mxolisi } \\
\text { Nxasana to } \\
\text { hold office } \\
\text { of NDPP } \\
\text { initiated } \\
\text { by Zuma, } \\
\text { followed by } \\
\text { litigation }\end{array}$ & $\begin{array}{l}\text { - National } \\
\text { Prosecution } \\
\text { Authority }\end{array}$ \\
\hline $\begin{array}{l}\text { Political } \\
\text { killings in } \\
\text { KZN }\end{array}$ & $\begin{array}{l}\text { Established in } \\
\text { October } 2016 . \text { The } \\
\text { report was released } \\
\text { in May } 2018 .\end{array}$ & $\begin{array}{l}\text { On } 28 \text { October 2016, the Premier of the } \\
\text { Province of KwaZulu-Natal established a } \\
\text { Commission of Enquiry into the Underlying } \\
\text { Causes of the Murder of Politicians in KwaZulu- } \\
\text { Natal (KZN). }\end{array}$ & $\begin{array}{l}\text { - Moerane } \\
\text { Commission } \\
\text { of Enquiry }\end{array}$ & $\begin{array}{l}\text { - KZN Provincial } \\
\text { Government } \\
\text { - KZN Local } \\
\text { Governments }\end{array}$ \\
\hline
\end{tabular}




\begin{tabular}{|c|c|c|c|c|}
\hline $\begin{array}{l}\text { Case Study } \\
\text { in State } \\
\text { Capture }\end{array}$ & Status & Summary Description & $\begin{array}{l}\text { Investigation } \\
\text { Body / } \\
\text { Source of } \\
\text { Evidence }\end{array}$ & $\begin{array}{l}\text { Government } \\
\text { Entity } \\
\text { Implicated }\end{array}$ \\
\hline \multicolumn{5}{|c|}{ Scandals Connected to Jacob Zuma, Guptas, Other Key Networks and ANC Politics } \\
\hline \multicolumn{5}{|c|}{ State Capture of State-Owned Enterprises and Government Departments } \\
\hline $\begin{array}{l}\text { Interference } \\
\text { in operations } \\
\text { at the SABC }\end{array}$ & $\begin{array}{l}\text { The Ad Hoc } \\
\text { Committee was } \\
\text { established in } \\
\text { November } 2016 \\
\text { and final report } \\
\text { was tabled on } \\
24 \text { February } 2017 .\end{array}$ & $\begin{array}{l}\text { Parliamentary Ad Hoc Committee on the } \\
\text { SABC Board Inquiry into mismanagement and } \\
\text { interference in SABC operations. Findings } \\
\text { include evidence of Minister Faith Muthambi's } \\
\text { interference in the organisation and editorial } \\
\text { interference, in the firing of SABC } 8 \text { who } \\
\text { protested censorship of the national broadcaster } \\
\text { (on instruction from COO Hlaudi Motsoeneng). It } \\
\text { should be noted that the inquiry was preceded } \\
\text { by an investigation by the Public Protector. } \\
\text { Details are contained in the } 2014 \text { report titled } \\
\text { When Governance and Ethics Fail. }\end{array}$ & $\begin{array}{l}\text { - Parliamen- } \\
\text { tary Inquiry } \\
\text { - Preceded by } \\
\text { an investi- } \\
\text { gation by } \\
\text { the Public } \\
\text { Protector }\end{array}$ & $\begin{array}{l}\text { - SABC } \\
\text { (Department } \\
\text { of Communi- } \\
\text { cation) }\end{array}$ \\
\hline \multirow[t]{2}{*}{$\begin{array}{l}\text { Passenger } \\
\text { Rail Agency } \\
\text { of South } \\
\text { Africa } \\
\text { (PRASA) }\end{array}$} & $\begin{array}{l}\text { Complaints were } \\
\text { lodged in } 2012 \\
\text { and the report } \\
\text { was released in } \\
\text { August } 2015 \text {. }\end{array}$ & $\begin{array}{l}\text { Several cases of "mismanagement and } \\
\text { irregularities" regarding various contracts. } \\
\text { Lucky Montana was CEO at the time. One of } \\
\text { the remedial actions stipulated that National } \\
\text { Treasury was to investigate all PRASA contracts } \\
\text { from } 2012 \text { onwards with a value of R10 million } \\
\text { or more. National Treasury implemented the } \\
\text { remedial action which resulted in several } \\
\text { investigations, the details of which were leaked } \\
\text { to the public. }\end{array}$ & $\begin{array}{l}\text { - Public } \\
\text { Protector's } \\
\text { Derailed } \\
\text { report on } \\
\text { PRASA } \\
\text { - Numerous } \\
\text { investiga- } \\
\text { tions }\end{array}$ & $\begin{array}{l}\text { - PRASA } \\
\text { - Department of } \\
\text { Transport }\end{array}$ \\
\hline & $\begin{array}{l}\text { In June } 2017, \\
\text { Parliament directed } \\
4 \text { committees to } \\
\text { investigate state } \\
\text { capture. Committee } \\
\text { hearings were not } \\
\text { completed. }\end{array}$ & $\begin{array}{l}\text { In terms of the parliamentary directive, the } \\
\text { Portfolio Committee on Transport was requested } \\
\text { to establish an Inquiry into State Capture at } \\
\text { PRASA. However, the Portfolio Committee noted } \\
\text { that PRASA was not mentioned in the Public } \\
\text { Protector's State of Capture report and decided } \\
\text { they would focus on the various investigation } \\
\text { reports produced for National Treasury (as } \\
\text { recommended in Derailed report). }\end{array}$ & $\begin{array}{l}\text { - Portfolio } \\
\text { Committee } \\
\text { on Transport }\end{array}$ & $\begin{array}{l}\text { - PRASA } \\
\text { - Department of } \\
\text { Transport }\end{array}$ \\
\hline $\begin{array}{l}\text { Eskom } \\
\text { Inquiry into } \\
\text { State Capture }\end{array}$ & $\begin{array}{l}\text { In June } 2017 \text {, } \\
\text { Parliament directed } \\
4 \text { committees } \\
\text { to investigate } \\
\text { state capture. } \\
\text { Public Enterprises } \\
\text { Committee } \\
\text { report on Eskom } \\
\text { was released in } \\
\text { November } 2018 .\end{array}$ & $\begin{array}{l}\text { Extensive hearings were held by the Committee } \\
\text { detailing much of the evidence presented in } \\
\text { the Public Protector's report. The Committee } \\
\text { presented recommendations and compiled } \\
\text { a final report detailing their findings. These } \\
\text { included findings that Ministers Lynne Brown } \\
\text { and Malusi Gigaba were negligent and had to } \\
\text { be held accountable. Also recommended that } \\
\text { criminal investigations be undertaken against } \\
\text { the relevant Eskom executives. }\end{array}$ & $\begin{array}{l}\text { - Parliamen- } \\
\text { tary Inquiry }\end{array}$ & $\begin{array}{l}\text { - Eskom } \\
\text { - Department } \\
\text { of Public } \\
\text { Enterprises }\end{array}$ \\
\hline $\begin{array}{l}\text { Nugent } \\
\text { Commission } \\
\text { - SARS } \\
\text { Inquiry }\end{array}$ & $\begin{array}{l}\text { The Inquiry was } \\
\text { constituted on } \\
24 \text { May } 2018 \text { and } \\
\text { the final report } \\
\text { was released in } \\
\text { December } 2018 \text {. }\end{array}$ & $\begin{array}{l}\text { Commission of Inquiry into tax administration } \\
\text { and governance by South African Revenue } \\
\text { Service (SARS). Tom Moyane was fired based on } \\
\text { the interim report released in September } 2018 . \\
\text { The inquiry found that Moyane, with the help of } \\
\text { consultancy company Bain, had implemented } \\
\text { restructuring of the organisation, resulting in } \\
\text { gross mismanagement and erosion of SARS. } \\
\text { Moyane motivated the restructuring based on } \\
\text { the "rogue unit" narrative that has been the } \\
\text { subject of several other debunked investigations } \\
\text { and the subject of much litigation. }\end{array}$ & $\begin{array}{l}\text { - Judicial } \\
\text { Commission } \\
\text { of Inquiry } \\
\text { - Court cases } \\
\text { around the } \\
\text { "rogue unit" } \\
\text { narrative }\end{array}$ & $\begin{array}{l}\text { - SARS } \\
\text { (National } \\
\text { Treasury) }\end{array}$ \\
\hline
\end{tabular}




\begin{tabular}{|c|c|c|c|c|}
\hline $\begin{array}{l}\text { Case Study } \\
\text { in State } \\
\text { Capture }\end{array}$ & Status & Summary Description & $\begin{array}{l}\text { Investigation } \\
\text { Body / } \\
\text { Source of } \\
\text { Evidence }\end{array}$ & $\begin{array}{l}\text { Government } \\
\text { Entity } \\
\text { Implicated }\end{array}$ \\
\hline \multicolumn{5}{|c|}{ Scandals Connected to Jacob Zuma, Guptas, Other Key Networks and ANC Politics } \\
\hline \multicolumn{5}{|c|}{ State Capture of State-Owned Enterprises and Government Departments } \\
\hline $\begin{array}{l}\text { Commission } \\
\text { of Inquiry } \\
\text { into Public } \\
\text { Investment } \\
\text { Corporation } \\
\text { (PIC) }\end{array}$ & $\begin{array}{l}\text { In October } 2018 \text {, } \\
\text { the Commission } \\
\text { was constituted, } \\
\text { and the final report } \\
\text { was released in } \\
\text { March } 2020 .\end{array}$ & $\begin{array}{l}\text { Commission of Inquiry into allegations of } \\
\text { impropriety regarding Public Investment } \\
\text { Corporation (PIC). There were extensive hearings } \\
\text { on various 'dodgy' deals the PIC entered } \\
\text { into and details of political and executive } \\
\text { interference in the operations and decision- } \\
\text { making processes of the investment agency. }\end{array}$ & $\begin{array}{l}\text { - Judicial } \\
\text { Commission } \\
\text { of Inquiry }\end{array}$ & $\begin{array}{l}\text { - PIC (National } \\
\text { Treasury) }\end{array}$ \\
\hline $\begin{array}{l}\text { South African } \\
\text { Social } \\
\text { Security } \\
\text { Agency } \\
\text { (SASSA) }\end{array}$ & $\begin{array}{l}\text { Various } \\
\text { Constitutional Court } \\
\text { cases from } 2011 \\
\text { to } 2018 \text { resulted } \\
\text { in removal of CPS } \\
\text { as service provider } \\
\text { to SASSA. }\end{array}$ & $\begin{array}{l}\text { In 2014, South African Social Security Agency's } \\
\text { (SASSA) } 2012 \text { contract with CPS was found } \\
\text { to be irregular and invalid, however, due to the } \\
\text { importance of ensuring beneficiaries received } \\
\text { grants, CPS continued to be the service } \\
\text { providers until } 2018 \text {. Following a March } 2017 \\
\text { ruling, the Constitutional Court instituted a } \\
\text { Section } 38 \text { Inquiry into Minister Bathabile } \\
\text { Dlamini's personal liability for the narrowly } \\
\text { averted grant payment crisis. }\end{array}$ & $\begin{array}{l}\text { Primary } \\
\text { sources: } \\
\text { - AllPay court } \\
\text { case } \\
\text { - Black Sash } \\
\text { court case }\end{array}$ & - SASSA \\
\hline $\begin{array}{l}\text { South African } \\
\text { Airways (SAA) } \\
\text { and SAA } \\
\text { Technical }\end{array}$ & $\begin{array}{l}\text { Court case } \\
\text { to have Dudu } \\
\text { Myeni declared a } \\
\text { delinquent director } \\
\text { was launched } \\
\text { in } 2017 .\end{array}$ & $\begin{array}{l}\text { Court case was launched in } 2017 \text { by Outa and } \\
\text { the SAA Pilots' Association (SAAPA) to declare } \\
\text { Myeni a delinquent director in terms of the } \\
\text { Companies Act, based on her actions while she } \\
\text { was chairperson of the SAA Board. In 2020, the } \\
\text { High Court declared Myeni a delinquent director } \\
\text { for life. A significant amount of new evidence } \\
\text { also emerged through the Zondo Commission, } \\
\text { outlining how the operations at SAA were } \\
\text { undermined and how Myeni and others abused } \\
\text { their positions of authority. }\end{array}$ & $\begin{array}{l}\text { - Court } \\
\text { papers } \\
\text { - Zondo } \\
\text { Commission }\end{array}$ & $\begin{array}{l}\text { - SAA } \\
\text { - SAA Technical }\end{array}$ \\
\hline $\begin{array}{l}\text { Gupta Family } \\
\text { Naturalisation }\end{array}$ & $\begin{array}{l}\text { In June } 2017, \\
\text { Parliament directed } \\
4 \text { committees to } \\
\text { investigate state } \\
\text { capture. Final } \\
\text { report was tabled } \\
14 \text { March } 2019 .\end{array}$ & $\begin{array}{l}\text { Portfolio Committee on Home Affairs Inquiry into } \\
\text { the Gupta Family Naturalisation was established } \\
\text { in terms of the Parliamentary directive. Hearings } \\
\text { formally started on } 12 \text { September 2018. Final } \\
\text { report was tabled on } 14 \text { March 2019. Questions } \\
\text { were raised around contracts with Visa } \\
\text { Facilitation Services. This matter is ongoing as } \\
\text { of December } 2020 \text {. }\end{array}$ & $\begin{array}{l}\text { - Portfolio } \\
\text { Committee } \\
\text { on Home } \\
\text { Affairs }\end{array}$ & $\begin{array}{l}\text { - Department of } \\
\text { Home Affairs }\end{array}$ \\
\hline $\begin{array}{l}\text { Inquiry into } \\
\text { State Capture } \\
\text { related to } \\
\text { Gupta-owned } \\
\text { mines }\end{array}$ & $\begin{array}{l}\text { In June } 2017, \\
\text { Parliament directed } \\
4 \text { committees } \\
\text { to investigate } \\
\text { state capture. }\end{array}$ & $\begin{array}{l}\text { Though the Committee drafted a term of } \\
\text { reference for the Inquiry, the activities of holding } \\
\text { hearings and consolidating the evidence never } \\
\text { materialised beyond questions being put to then } \\
\text { Minister Zwane. }\end{array}$ & $\begin{array}{l}\text { - Portfolio } \\
\text { Committee } \\
\text { on Mineral } \\
\text { Resources }\end{array}$ & $\begin{array}{l}\text { - Department } \\
\text { of Mineral } \\
\text { Resources }\end{array}$ \\
\hline
\end{tabular}




\begin{tabular}{|c|c|c|c|c|}
\hline $\begin{array}{l}\text { Case Study } \\
\text { in State } \\
\text { Capture }\end{array}$ & Status & Summary Description & $\begin{array}{l}\text { Investigation } \\
\text { Body / } \\
\text { Source of } \\
\text { Evidence }\end{array}$ & $\begin{array}{l}\text { Government } \\
\text { Entity } \\
\text { Implicated }\end{array}$ \\
\hline \multicolumn{5}{|c|}{ Scandals Connected to Jacob Zuma, Guptas, Other Key Networks and ANC Politics } \\
\hline \multicolumn{5}{|c|}{ State Capture of State-Owned Enterprises and Government Departments } \\
\hline \multirow{3}{*}{$\begin{array}{l}\text { Various } \\
\text { investigations } \\
\text { relating to } \\
\text { State Capture } \\
\text { at Eskom }\end{array}$} & 2015 & $\begin{array}{l}\text { In } 2015 \text {, Dentons produced an interim report } \\
\text { on their investigations into Status of Business } \\
\text { and Challenges at Eskom. Their investigation } \\
\text { was halted. }\end{array}$ & - Eskom & - Eskom \\
\hline & \multirow[t]{2}{*}{2017} & $\begin{array}{l}\text { In 2017, PricewaterhouseCoopers (PwC) was } \\
\text { appointed by National Treasury to investigate } \\
\text { Eskom's Coal Procurement Processes. Damning } \\
\text { findings were made in relation to Gupta-owned } \\
\text { Tegeta mine contracts and poor coal quality. }\end{array}$ & - Eskom & - Eskom \\
\hline & & $\begin{array}{l}\text { G9 was contracted by Eskom to investigate } \\
\text { the Trillian/McKinsey contracts. Interim report } \\
\text { presented to Board of Eskom in August } 2017 . \\
\text { The investigation remained incomplete, and } \\
\text { no report is available in the public domain. } \\
\text { Evidence from the investigation was presented } \\
\text { in the Parliamentary Inquiry into Eskom } \\
\text { State Capture. }\end{array}$ & $\begin{array}{l}\text { - National } \\
\text { Treasury }\end{array}$ & - Eskom \\
\hline $\begin{array}{l}\text { National } \\
\text { Treasury } \\
\text { Fundudzi } \\
\text { reports, } \\
\text { related to } \\
\text { Eskom and } \\
\text { Transnet (x3) }\end{array}$ & $\begin{array}{l}\text { Final reports } \\
\text { compiled in } \\
\text { November } 2018 \\
\text { and released to } \\
\text { the public shortly } \\
\text { thereafter. }\end{array}$ & $\begin{array}{l}\text { Investigations requested by National Treasury } \\
\text { of alleged corruption at Transnet and Eskom. } \\
\text { The three reports focused on Eskom (general), } \\
\text { the contracts related to Trillian/McKinsey and } \\
\text { Transnet Locomotives. }\end{array}$ & $\begin{array}{l}\text { - National } \\
\text { Treasury } \\
\text { Fundudzi }\end{array}$ & $\begin{array}{l}\text { - Eskom } \\
\text { - Transnet }\end{array}$ \\
\hline \multirow[t]{2}{*}{$\begin{array}{l}\text { Transnet } \\
\text { Locomotive } \\
\text { Contracts }\end{array}$} & \multirow[t]{2}{*}{$\begin{array}{l}\text { Investigations } \\
\text { commenced in } \\
\text { December } 2017 \\
\text { and reports on } \\
\text { findings submitted } \\
\text { during } 2018 \text {. }\end{array}$} & $\begin{array}{l}\text { Werksmans Attorneys was appointed in } \\
\text { December } 2017 \text { to undertake an investigation } \\
\text { into the } 1064 \text { Transnet Locomotives } \\
\text { procurement process, however, the investigation } \\
\text { was halted. No report in the public domain. }\end{array}$ & - Werksmans & - Transnet \\
\hline & & $\begin{array}{l}\text { Mncedisi Ndlovu \& Sedumedi (MNS) Attorneys } \\
\text { was then appointed to investigate } 1064 \\
\text { locomotives procurement process. The report } \\
\text { is not in the public domain, but media indicates } \\
\text { that recommendations mirror the Werksmans' } \\
\text { findings and recommends that Molefe face } \\
\text { criminal charges. }\end{array}$ & $\begin{array}{l}\text { - Mncedisi } \\
\text { Ndlovu \& } \\
\text { Sedumedi }\end{array}$ & - Transnet \\
\hline $\begin{array}{l}\text { Inquiry into } \\
\text { State Capture } \\
\text { at Transnet } \\
\text { and Denel }\end{array}$ & $\begin{array}{l}\text { In June } 2017, \\
\text { Parliament directed } \\
4 \text { committees to } \\
\text { investigate state } \\
\text { capture. Committee } \\
\text { hearings were not } \\
\text { completed. }\end{array}$ & $\begin{array}{l}\text { A detailed information booklet was prepared } \\
\text { in relation to Transnet, however, hearings were } \\
\text { not held before the end of term of Parliament. } \\
\text { Following National elections in } 2019 \text {, it } \\
\text { was decided that outstanding Inquiries into } \\
\text { state capture be postponed indefinitely until } \\
\text { conclusion of the Zondo Commission. }\end{array}$ & $\begin{array}{l}\text { - Portfolio } \\
\text { Committee } \\
\text { on Public } \\
\text { Enterprises }\end{array}$ & $\begin{array}{l}\text { - Transnet } \\
\text { - Denel }\end{array}$ \\
\hline
\end{tabular}




\begin{tabular}{|c|c|c|c|c|}
\hline $\begin{array}{l}\text { Case Study } \\
\text { in State } \\
\text { Capture }\end{array}$ & Status & Summary Description & $\begin{array}{l}\text { Investigation } \\
\text { Body / } \\
\text { Source of } \\
\text { Evidence }\end{array}$ & $\begin{array}{l}\text { Government } \\
\text { Entity } \\
\text { Implicated }\end{array}$ \\
\hline \multicolumn{5}{|c|}{ Scandals Connected to Jacob Zuma, Guptas, Other Key Networks and ANC Politics } \\
\hline \multicolumn{5}{|c|}{ Law Enforcement and the Security Cluster } \\
\hline $\begin{array}{l}\text { Enquiry into } \\
\text { Jiba and } \\
\text { Mrwebi's } \\
\text { fitness to } \\
\text { hold office } \\
\text { at NPA }\end{array}$ & $\begin{array}{l}\text { Established in } \\
\text { November } 2018 . \\
\text { Report was issued } \\
\text { in April } 2019 .\end{array}$ & $\begin{array}{l}\text { Presidential Enquiry into the fitness to hold } \\
\text { office of suspended NPA senior advocates } \\
\text { Nomgcobo Jiba and Lawrence Mrwebi. NPA's } \\
\text { deputy head Jiba, and Mrwebi, the head of } \\
\text { the Specialised Commercial Crimes Unit, were } \\
\text { suspended in October } 2018 \text { by President Cyril } \\
\text { Ramaphosa. The Inquiry was headed by retired } \\
\text { Constitutional Court Justice Yvonne Mokgoro. } \\
\text { Jiba and Mrwebi were accused of improper } \\
\text { conduct in their handling of cases involving } \\
\text { former crime intelligence head Richard Mdluli, } \\
\text { as well as former KwaZulu-Natal Hawks boss } \\
\text { Johan Booysen. }\end{array}$ & $\begin{array}{c}\text { - Mokgoro } \\
\text { Enquiry }\end{array}$ & $\begin{array}{l}\text { - } \text { National } \\
\text { Prosecuting } \\
\text { Authority }\end{array}$ \\
\hline $\begin{array}{l}\text { High-Level } \\
\text { Review Panel } \\
\text { on the State } \\
\text { Security } \\
\text { Agency (SSA) }\end{array}$ & $\begin{array}{l}\text { Established in June } \\
2018 \text { and final } \\
\text { report was sent to } \\
\text { the President in } \\
\text { December } 2018 .\end{array}$ & $\begin{array}{l}\text { The High-Level Review Panel into the SSA } \\
\text { was established by President Ramaphosa in } \\
\text { June 2018. The key finding was a serious } \\
\text { politicisation and factionalisation of the } \\
\text { intelligence community over the past decade } \\
\text { or more. This resulted in "an almost complete } \\
\text { disregard for the Constitution, policy, legislation } \\
\text { and other prescripts, and [turned] our civilian } \\
\text { intelligence community into a private resource } \\
\text { to serve the political and personal interests of } \\
\text { particular individuals" (High-Level Review Panel } \\
\text { on the SSA, 2018, p. ii). }\end{array}$ & $\begin{array}{l}\text { - Review } \\
\text { Panel } \\
\text { established } \\
\text { by President } \\
\text { Ramaphosa }\end{array}$ & - SSA \\
\hline $\begin{array}{l}\text { Various court } \\
\text { cases against } \\
\text { persons } \\
\text { within law } \\
\text { enforcement }\end{array}$ & Ongoing. & $\begin{array}{l}\text { Though testimony and evidence have been } \\
\text { presented at the Zondo Commission, it is } \\
\text { understood that no definitive findings will be } \\
\text { made regarding the capture of law enforcement } \\
\text { under the Zuma administration. Since } 2012 \\
\text { onwards, there were several court cases } \\
\text { that were pursued against individuals in law } \\
\text { enforcement, all of which have been either } \\
\text { dismissed or withdrawn. Most noteworthy are } \\
\text { the cases involved, amongst others: Anwa } \\
\text { Dramat and Shadrack Sibiya of the Hawks } \\
\text { (and Robert McBride from Independent Police } \\
\text { Investigative Directorate [IPID]) for allegations } \\
\text { related to the "Zimbabwean rendition" matter; } \\
\text { Johan Booysen for alleged racketeering as part } \\
\text { of "Cato Manor hit squad"; and the various } \\
\text { senior officials accused of being part of the } \\
\text { "rogue" intelligence unit at SARS. Other court } \\
\text { cases that have provided significant evidence } \\
\text { indicating the capture of law enforcement relate } \\
\text { to the irregular appointed allies of the Shadow } \\
\text { State capture network or the irrational removal } \\
\text { of potential opponents holding senior positions } \\
\text { in law enforcement. Example is the irregular } \\
\text { removal of Mxolisi Nxasana as National Director } \\
\text { of Public Prosecutions (NDPP). }\end{array}$ & $\begin{array}{l}\text { - Various } \\
\text { court cases, } \\
\text { proceedings } \\
\text { in Parlia- } \\
\text { ment } \\
\text { - Zondo } \\
\text { Commission }\end{array}$ & $\begin{array}{l}\text { - NPA } \\
\text { - SAPS } \\
\text { - Hawks } \\
\text { - IPID }\end{array}$ \\
\hline
\end{tabular}




\begin{tabular}{|c|c|c|c|c|}
\hline $\begin{array}{l}\text { Case Study } \\
\text { in State } \\
\text { Capture }\end{array}$ & Status & Summary Description & $\begin{array}{l}\text { Investigation } \\
\text { Body / } \\
\text { Source of } \\
\text { Evidence }\end{array}$ & $\begin{array}{l}\text { Government } \\
\text { Entity } \\
\text { Implicated }\end{array}$ \\
\hline \multicolumn{5}{|c|}{ Scandals Connected to Jacob Zuma, Guptas, Other Key Networks and ANC Politics } \\
\hline \multicolumn{5}{|c|}{ Investigations concerning Private Sector } \\
\hline $\begin{array}{l}\text { Budlender } \\
\text { report on } \\
\text { Trillian }\end{array}$ & $\begin{array}{l}\text { Released in } \\
\text { June } 2017 .\end{array}$ & $\begin{array}{l}\text { Trillian Holdings Board appointed Geoff } \\
\text { Budlender SC to undertake investigations into } \\
\text { State Capture allegations at Trillian Capital. } \\
\text { Detailed accounts from whistle-blowers } \\
\text { highlighted how information was withheld by } \\
\text { senior management at Trillian. }\end{array}$ & - Trillion & - Eskom \\
\hline $\begin{array}{l}\text { Collapse of } \\
\text { VBS Mutual } \\
\text { Bank }\end{array}$ & $\begin{array}{l}\text { Investigation } \\
\text { launched in } \\
\text { April } 2018 \text { and } \\
\text { the report was } \\
\text { released in } \\
\text { October } 2018 .\end{array}$ & $\begin{array}{l}\text { Minister of Finance placed VBS under } \\
\text { curatorship with effect from } 11 \text { March 2018. In } \\
\text { April 2018, the Deputy Governor of the South } \\
\text { African Reserve Bank instituted an investigation } \\
\text { into VBS. The outcomes of the investigation } \\
\text { showed blatant fraud and corruption by senior } \\
\text { executives/Board and how they extracted } \\
\text { money from the bank. Municipal funds were } \\
\text { illegally deposited with VBS (senior ANC and } \\
\text { EFF politicians have been implicated). }\end{array}$ & $\begin{array}{l}\text { - SARB } \\
\text { investiga- } \\
\text { tion report } \\
\text { VBS Mutual } \\
\text { Bank - The } \\
\text { Great Bank } \\
\text { Heist }\end{array}$ & $\begin{array}{l}\text { - Several } \\
\text { Provincial and } \\
\text { Municipal } \\
\text { Officials } \\
\text { (Limpopo } \\
\text { Government) } \\
\text { - SOEs } \\
\text { (particularly } \\
\text { PRASA) }\end{array}$ \\
\hline $\begin{array}{l}\text { SA Institute } \\
\text { of Chartered } \\
\text { Accountants' } \\
\text { (SAICA) } \\
\text { investigation } \\
\text { into KPMG }\end{array}$ & $\begin{array}{l}\text { Final report was } \\
\text { handed to SAICA in } \\
\text { December } 2018 .\end{array}$ & $\begin{array}{l}\text { SA Institute of Chartered Accountants (SAICA) } \\
\text { established an Inquiry to investigate state } \\
\text { capture related allegations of misconduct of its } \\
\text { members who worked for KPMG. The Inquiry } \\
\text { chaired by advocate Dumisa Ntsebeza held } \\
\text { public hearings and handed its final report to } \\
\text { SAICA in December 2018. Indications are that } \\
\text { the final report will not be made public until all } \\
\text { investigations and disciplinary hearings have } \\
\text { been finalised. }\end{array}$ & - SAICA & - Guptas \\
\hline Bell Pottinger & $\begin{array}{l}2017 \text { investigation } \\
\text { by PRCA. }\end{array}$ & $\begin{array}{l}\text { In 2016, the Guptas appointed British PR } \\
\text { company, Bell Pottinger, who developed and } \\
\text { promoted a campaign that underpinned the RET } \\
\text { and WMC narratives. In 2017, there was an } \\
\text { independent law firm review by Herbert Smith } \\
\text { Freehills resulting in Bell Pottinger's expulsion } \\
\text { from the Public Relations and Communications } \\
\text { Association (PRCA). }\end{array}$ & $\begin{array}{l}\text { - PRCA } \\
\text { - GuptaLeaks } \\
\text { - Ongoing } \\
\text { research } \\
\text { on disinfor- } \\
\text { mation }\end{array}$ & - Guptas \\
\hline
\end{tabular}

